\title{
EFFECT OF WHEAT BISCUIT ON THE PREVENTION OF VOMITTING IN EARLY PREGNANT WOMEN
}

\author{
Halimatus Saidah
}

\author{
Faculty of Health, Universitas Kadiri, East Java
}

\begin{abstract}
Background: Vomiting during pregnancy is a common occurrence, with as many as $60-70 \%$ of pregnant women experiencing vomiting as an unpleasant symptom of morning sickness. Vomiting during pregnancy if left untreated may becomesevere. The impact is decreased fluid and body electrolyte, blood circulation inhibition, and eventually disrupted growth of the fetus. An empty stomach can cause nausea. Wheat biscuit intake may have an effect on the prevention of nausea and vomiting in pregnant women. Digestive biscuits that are made from whole grain or whole wheat are good as a snack as they have a lot of dietary fibre. This dietary fibre helps regularize bowel movement and clear up constipation. Since constipation is a major side effect of pregnancy consuming these biscuits may actually help pregnant women. This study aimed to determine the effect of wheat biscuit on the prevention of vomiting during early pregnancy.

Subjects and Method: This was a quasi experiment with one group pre and post design. The study was conducted at Mojoroto, Sukarame, Kediri, East Java. A sample of 12 pregnant women of first trimester with vomiting was selected for this study. The dependent variable was vomiting frequency. The independent variable was wheat biscuit intake. The data were collected by questionnaire. The match data were analyzed by Mc Nemar test.

Results: Before intervention, 6 (50\%) ofpregnant women had moderate vomiting and $6(50 \%)$ had mild vomiting. After intervention, 1 (8\%) ofpregnant women had moderate vomiting, 2 (17\%) had mild vomiting, and 9 (75\%) had no vomiting.

Conclusion: Wheat biscuit seems beneficial to prevent vomiting during pregnancy. More studies with randomized control trial with a large sample are suggested to provide stronger evidence.
\end{abstract}

Keywords: vomiting, wheat biscuit, pregnancy

\section{Correspondence:}

Halimatus Saidah. Faculty of Health, Universitas Kadiri, East Java.

Email: Halimatus.saidah@unik-kediri.ac.id.

Mid-International Conference in Public Health, Best Western Premiere Hotel, Solo, Indonesia, 18-19 April 2018 | 214 https://doi.org/10.26911/mid.icph.2018.03.50 